\title{
Annual Prize Awards of the Paris Academy of Sciences.
}

$A^{T}$ the annual public meeting of the Paris Academy of Sciences on Dec. 17, the prizes and grants awarded in 1928 were announced as follows :

Mathematics. - The Poncelet prize to Gaston Julia for the whole of his mathematical work; the Francœur prize to Szolem Mandelbrojt for his work in mathematical analysis.

Mechanics.-The Montyon prize to Filippo Burzio for his work in ballistics ; the Henri de Parville prize to F. C. Haus for his researches in aeronautics.

Astronomy.-The Lalande prize to Bernard Lyot for his work on the polarisation of the planets; the Valz prize to Georges van Biesbroeck for the whole of his astronomical work; the Janssen medal to William Wright for the whole of his work.

Geography.-The Delalande-Guérineau prize to Paul Serre for his scientific collections during the last thirty years ; the Gay prize to Henri Gaussen for his contributions to the study of the flora, climate, and geology of the eastern Pyrenees ; the Tchihatchef foundation to Eugène Poilane for his botanical and entomological collections in Indo-China ; the Binoux prize (in equal parts) between Carlos Ibañez de Ibero for his work in connexion with the proposed tunnel under the straits of Gibraltar, and the late Paul Soulier for his work on the origin and evolution of the earth's relief.

Navigation.-The prize of six thousand francs to Dieudonné Costes and Joseph Marie le Brix for their remarkable flight; the Plumey prize to Albert Thuloup for his memoir on the fatigue of thin pipes.

Physics. - The L. Lacaze prize to Charles Mauguin for the whole of his work in crystallography; the Kastner-Boursault prize to Pierre Auger for his work on the structure of the atom; the Hébert prize to Jean Granier for his book on electrical measurements ; the Hughes prize to Jean Thibaud for his work on the $\mathrm{X}$-rays; the Danton foundation to Pierre Bricout for enabling him to continue his researches on the measurement of radiation; the Clément Félix foundation to Paul Woog for the continuation of his work on oiliness.

Chemistry.-The Montyon prize (unhealthy trades) to Mme. Mélanie Rosenblatt, for her work on the study of poison gas and of the means of protection against it ; the Jecker prize to Victor Auger for the whole of his work; the L. La Caze prize to Paul Pascal for his work in pure and applied chemistry; the Cahours foundation to Mme. N. Demassieux for her physicochemical work ; the Houzeau prize to Albert Portevin for his work in metallurgy.

Mineralogy and Geology.-The Victor Raulin prize to Jean Orcel for his work on the chlorites; the James Hall prize to Jean Piveteau for his memoir on the Permian of southern Madagascar and its quadruped vertebrate fauna.

Botany.-The Desmazières prize to Léonidas Grigoraki for his work on parasitic fungi; the Montagne prize to Roger Werner for his memoir on biological and experimental researches on the ascomycetes of lichens ; the de Coiney prize to Mlle. Gabrielle Bonne for her memoir on the pedicel and flower of the Rosaceæ. An honorable mention to (the late) Eugène Perrier de la Bathie.

Anatomy and Zoology.-The Cuvier prize to Louis Boutan for the whole of his zoological work; the Savigny prize to J. L. Dantan for his study of the plankton flora of the bay of Algiers and other biological work; the Jean Thore prize to Étienne Hubault for his work entitled "Contribution à l'étude des Invertébrés torrenticoles."

Medicine and Surgery.-Montyon prizes to Maurice Chiray and Ion Pavel (2500 francs) for their work on the gall-bladder ; Edmond Papin (2500 franes) for his book on the surgery of the kidney; Gustave Worms (2500 francs) for his memoir on the pathological anatomy of the thymus. Honourable mentions (1500 francs) to Albert Berthelot, to Gaston Ramon, and to Mlle. Germaine Amoureux for their biochemical researches on the toxins and their derivatives; to Charles Foix and Julien Marie for their work entitled "La sclérose cérébrale centro-lobaire à tendance symétrique, ses rapports avec l'encéphalite périaxale diffuse"; to Édouard Schoull and Louis Weiller for their work on the use of creosote in the treatment of pneumococcus. Citations to Pierre Dombray, Charles Lombard, Jean Nicolaïdi, and to A. W. Turner and J. Davesne. The Barbier prize to Joseph Belot and François Lepennetier for their memoir on the radiographic anatomy of the normal skeleton; the Bréant prize between Georges Blanc (3000 francs) for his experimental researches on herpes, and Édouard Rist (2000 francs) for his work on tuberculosis; the Godard prize to Paul Bordas for his. studies on the kidney and surrounding tissues; the Bellion prize to Noël Fiessinger and Henry Walter for their work on the functional exploration of the liver and hepatic insufficiency; the Larrey prize to Antony Rodiet and Fribourg-Blanc for their work on mental troubles and the War of 1914-1918.

Physiology.-The Montyon prize to Maurice Rose for his work on phototropism and on plankton; the La Caze prize to Louis Lapicque for the whole of his work in physiology; the Pourat prize to Robert Courrier for his work on the determinism of secondary sexual characters; the Martin-Damourette prize to Eugène Jamot for his researches on the treatment of sleeping sickness; the Philipeaux prize to François Granet for his work on the pseudobranch of fish.

Statistics.-The Montyon prize to Georges Darmois for his memoir on mathematical statistics.

History and Philosophy of Science.-The Binoux prize to André Metz for his work entitled "Une nouvelle philosophie des sciences : Le causalisme de M. Emile Meyerson" ; the Henri de Parville prize (2500 francs) to Alfred Chapuis and Edouard Gélis for their book "Monde des automates, étude historique et technique" ; also prizes ( 1000 francs each) for the books "Science et travail: Grande encyclo. pédie illustrée des nouvelles inventions" (editor J. L. Breton) and "Microbiologia aquaria e tecnica," by Gino de Rossi.

Medals.-Berthelot medals to Mme. Mélanie Rosenblatt, Victor Auger, and Albert Portevin.

General Prizes.-The prize founded by the State (Grand Prize of the mathematical sciences) to Georges Giraud for his work on partial differential equations; the Bordin prize to Louis Fage for his zoological work ; the Lallemand prize to Mlle. Fernande Coupin for her work on anthropoid apes; the Vaillant prize to Maurice Frechet for his work on abstract ensembles; the Estrade-Delcros prize to Pierre Jolibois for his chemical work; the Houllevigue prize between Paul Danguy for his researches on the flora of Madagascar and of Siberia, and Mme. Yvonne Gubler-Wahl for her work on the geological survey of France ; the Saintour prize to Émile Terroine for his researches on the physiology of nutrition; the Lonchampt prize to Maurice Javillier for the continuation of his work on the mineral composition of plants; the Wilde prize to Albert Pérard for his work in metrology and physical optics ; the Caméré prize to Louis Biette for his book entitled "Les chemins de fer urbains parisiens" ; the Roux prize to François Divisia for his memoir on rational economics; the Thorlet prize to Adolphe

No. 3091, VoL. 123] 
Richard ; the Albert lst of Monaco prize to A. Cotton for the continuation of his researches on powerful magnetic fields.

Special Foundations. - The Lannelongue foundation between Mmes. Cusco and Rück; the HelbronnerFould prize to Mme. Marcel Bertrand for assisting the publication of the collected researches of the late M. Bertrand.

Prizes of the Grandes Écoles.-The Laplace prize to Pierre Robert ; the L. E. Rivot prize between Pierre Robert, Alphonse Grange, Roger Dodu, and Marcel Davin.

Foundations for Scientific Research.-The Trémont foundation to André Charrueau for his researches on the equilibria of fluids; the Gegner foundation to Maurice Vèzes for his treatise on physical chemistry; the Jérome Ponti foundation to Pierre Cappe de Baillon for his researches on the teratology of insects ; the Hirn foundation to Maurice Gevrey for his work on partial differential equations; the Henri Becquerel foundation to Paul Lévy for his works on functional analysis.

\section{The Loutreuix Foundation.}

The Academy received 31 requests for grants from this foundation, 25 of which were acceded to as follows:

National Museum of Natural History, 11,000 francs for the establishment of a catalogue of the books in the laboratory libraries : 12,000 francs to the École Polytechnique for the use of the library; 2000 francs to M. Nicolas, director of the National Veterinary School of Alfort, for his biochemical researches on thiourea and its derivatives; 4000 francs to M. Maignon for continuing his researches, especially on the influence of the seasons and of the genital glands on basal metabolism and the specific dynamic action of foods in the dog; 4000 francs to the National Veterinary School of Lyons for the completion of sets of foreign periodicals in the library ; 4000 francs to the National Veterinary School of Toulouse for additions to its library ; 4000 francs to the National Agronomic Institute for the completion of sets of periodicals in its library interrupted by the War ; 3000 francs to Paul Nottin for his researches on the saccharification of starch.

Conservatoire national des Arts et Métiers.-5000 francs to Léon Guillet for the purchase of material for researches on the action of repeated stresses on metals and for the development of installations for thermal treatment ; $\mathbf{4 0 0 0}$ francs to the library for the purchase of books.
Grants other than to Institutions. - 5000 francs to René Jeannel for the publication of parts 57 to 59 of the zoological studies undertaken on material collected in the course of the expedition made by him (with $\mathbf{M}$. Alluaud) in Central Africa ; 5000 francs to Louis Bazy for his researches on the curative and preventative properties of the bacillus of paratuberculous enteritis of cattle and of its extracts; 5000 francs to Mme. Delage as the last contribution to the publication of the last volume of the biological annual ; 1000 franes to Édouard Doublet for the publication of a historical work on Gustave Lambert ; 2000 francs to Henri Douvillé for the research in the field of fossils permitting the completion of the study of the Rudist limestones of the Pyrenees; 5000 francs to the "Faune des Colonies françaises"; 2000 francs to Gaston Fayet to ensure the regular publication of the Bulletin of the Nice Observatory ; 5000 francs for the publication of material collected by the cruises of the Travailleur and the Talisman; 6000 francs to Henri Humbert to contribute to his studies of the flora of the high mountains of Madagascar and its comparison with that of tropical Africa; 3000 francs to the Institut d'Optique for the purchase of books to complete its library ; 8000 francs to Jean Mascart to contribute towards the cost of printing observations of work carried out or centralised at Lyons ; 5000 francs to the Paris Observatory for completing the publication of Lalande's catalogue ; 8000 francs to the Zo-Se Observatory to assist in the publication of observations made at this Observatory; 4000 francs to Jean Piveteau to undertake geological and palæontological researches in southern Tunis; 8000 francs to $J$. Risbec for the purchase of apparatus to enable him to carry on his biological researches in New Caledonia.

The Mme. Victor Noury foundation between Fernand Blondel (4000 francs) for his work on the geology of Indo-China, René Fortrat ( 3000 franes) for his work on spectroscopy, and Lucien Klotz (30,00 franes) for his work in connexion with the rights of authors and scientific men and the protection of scientific property ; the Bouchard foundation to Constantin Toumanoff for the continuation of his researches on the normal and pathological (microbial diseases) physiology of insects ; the Ray-Vaucouloux foundation to Claudius Regaud for the whole of his work on the action of radium and of the $\mathrm{X}$-rays on normal and on pathological tissues, with special reference to the use of the radiations in the treatment of various cancerous growths.

\section{Annual Meeting of the Mathematical Association.}

"WHERE you find a low standard of education, there you find with it dark superstition and enslavement to formulæ in every aspect of life." No reader of NATURE is likely to quarrel with this statement (liberally misquoted from memory) with which Mr. N. J. Chignell began his paper on "The Use and Abuse of Formulæ" at the annual meeting of the Mathematical Association on Jan. 7 and 8. Happiest among his examples of the general formulæ that are being questioned by a world awaking to thought, before he came to those which belong distinctively to mathematies or science, was this: "That a cloth cap must always be taken off in the presence of a top-hat." Not many years ago, the ensuing discussion would certainly have brought to light some of our dear old friends with their final argument that "memorising formulæ gets boys through who are too stupid to pass in any other way." These are not extinct ; but "the sun ariseth and they get them away together, and lay them down in their dens." Even the examiner, formerly the arch-enemy, looks now for understanding rather than memory, so Prof. Neville told us : there is much that the examiner can do to help, by forbidding the use of unproved formulæ or by setting a question to which no 'crammable' formulæ apply.

One of the quaintest of our modern superstitions is that the common methods of voting give us the representatives we want. A singularly interesting paper by Prof. J. E. A. Steggall, illustrated by numerous examples from his own experience at Dundee, showed how remarkably effective they can be in giving us just those representatives whom the majority decidedly prefer to do without. When two prizes for valour were to be awarded after the battle of Salamis, it is recorded that the commander of the contingent from every Greek state modestly recommended himself for the first prize and Themistocles for the second : the system of counting first places only would have left the greatest soldier of his time at the foot of the poll. Nearer home than that, it is no uncommon thing for $A$ to be elected out of three candidates on 